\title{
A Conflict on Baha'ism and Islam in 1922: Abdullah Cevdet and State Religious Agencies
}

\author{
Ayşe Polat*
}

\begin{abstract}
This paper investigates Abdullah Cevdet's 1922 article on Baha'ism as well the reaction of the state authorities, particularly that of two Meşihat councils. After briefly discussing the author's biography and journalistic activities, primarily his periodical lictihad, the paper focuses on the essay's content by investigating the historical context, namely, the post-World War I years, during which he articulated his ideas on Baha'ism as a religion of peace and nonviolence. Close attention is also paid to the distinctions Cevdet drew among Baha'ism, Islam, and Christianity regarding their essential origins and how they developed in human time, i.e. history. The rest of the article details the presence of Ottoman religious censorship mechanisms on periodical publications during the Armistice years. In this regard, the state's decision to authorize the Tetkik-i Mesahif ve Müellefat-ı Şeriyye Meclisi and the Daru'l-Hikmeti'l İslamiye to approve or reject Islamic publications are studied closely, especially with respect to their criticism of Cevdet's essay. The criteria and rationale they deployed in condemning it are analyzed through their own archival records.
\end{abstract}

Keywords: Abdullah Cevdet, Meşihat councils, Baha'ism, Islam, print, censorship.

Öz: Bu çalışmada Abdullah Cevdet'in 1922'de Baha'ilik ile ilgili yazdığı bir makale ve devlet otoritelerinin bilhassa Meşihat bünyesinde işleyen iki meclisin bu makaleye gösterdiği tepkiler ele alınmaktadır. Cevdet'in özgeçmişi ve gazetecilik faaliyetleri, özellikle yayınladığı İctihad mecmuası, hakkında kısa bir bilgi verilmesinin ardından, 1922'de Baha'ilik üzerine yazdığı makalesi kaleme alındığı tarihsel bağlamı çerçevesinde ele alınmaktadır. Cevdet'in Baha'ilik'i barış ve merhamet dini olarak vurgulamasında 1. Dünya Savaşı ve akabindeki gelişmelerin belirleyici rolü olduğu vurgulanmaktadır. Ayrıca Cevdet'in Baha'ilik'i İslam ve Hristiyanlık'la karşılaştırırken dinlerin öz ve tarihsel süreçleri şeklinde bir ayrım yaptığı öne sürülmektedir. Çalışmanın geri kalan kısmında Cevdet'in makalesinin sansürlenmesi özelinde Mütareke yıllarında Osmanlı'da mevcut olan dini yayınları (bilhassa dergi ve gazeteler) denetleme, kontrol ve yasaklama mekanizmalarına ve bu noktada Meşihat bünyesindeki Tetkik-i Mesahif ve Müellefat-ı Şeriyye Meclisi ve Daru'I-Hikmeti'l İslamiye adlı iki meclisin belirleyici rollerine vurgu yapılmaktadır. Bu iki meclisin arşiv kaynakları üzerinden onların Cevdet'in makalesini hangi kriter ve gerekçelerle eleştirip hukuki işleme tabi tuttukları tahlil edilmektedir.

Anahtar kelimeler: Abdullah Cevdet, Meşihat meclisleri, Baha'ilik, İslam, matbuat, sansür.

* Dr., Anthropology and Sociology of Religion.

Correspondence: polatayse@gmail.com. Address: Şemsi Efendi Sk. No:17, Beylerbeyi, İstanbul/ Turkey.

D0l: dx.doi.org/10.12658/human.society.5.10.M0156

İnsan ve Toplum, 5 (10), 2016 


\section{Introduction}

As one of the most prominent and most controversial late Ottoman intellectuals, Abdullah Cevdet's life and thought, including his views on religion, have received substantial scholarly attention (Hanioğlu, 1981; Alkan, 2005; Demir, 2011). This article diverges from those studies by focusing on his 1922 essay on Baha'ism and how the state administrators and religious cadres working under the Meşihat (the office of the Sheikh al-Islam) received it. Cevdet and his essay were targeted by two Meşihat councils, the Tetkik-i Mesahif ve Müellefat-ı Şeriyye Meclisi and the Daru'I-Hikmeti'l İslamiye, both of which were tasked with overseeing, approving, or rejecting publications. The stated rationale, including the legal categories they pursued, is examined closely. While his ideas on religion carried similarities, such as his praise of Baha'ism as a religion of reason, they were also significantly reshaped by ongoing historical circumstances and developments of World War I and its aftermath. Likewise, under the peculiar and challenging circumstances of the postwar years, the Ottoman imperial state still sought to preserve its control and authority over all publications' religious content. When asserting their control and censorship, the state agents appealed most frequently to the legally entrenched concern about protecting the people's religious convictions and sentiments from all types of injury.

Cevdet's articulations on religion assumed various forms, and his contemporaries as well as the scholars examining his thought adopted different perspectives on it. Specifically with regard to his views on Baha'ism, Şükrü Hanioğlu asserted that Cevdet considered it "an intermediary step between Islam and materialism" (Hanioğlu, 1995, p. 202) or, despite the new religion's ultimate failure, appealed to it as a "vehicle for reconciling materialism with religion" (Hanioğlu, 2005, p. 59). Necati Alkan claimed that Cevdet was not "as irreligious" as he was generally portrayed; he did not consider religion simply "as an instrument to reform society" but rather as true source of "peace, harmony, light and unity" (Alkan, 2005, p. 11). Hanioğlu's first studies analyzed Cevdet's political views and the formation of the Young Turk movement. His interest in Cevdet's ideas on religion emerges from these earlier works. As for Alkan, while his article on this essay is an important contribution, especially for providing English renderings of important primary documents on the topic, its ultimate goal of demonstrating Cevdet's genuine commitment to Baha'ism leads him to take some of Cevdet's statements at face value. For instance, Alkan concludes that "Cevdet was no enemy of religion but [rather] of bigotry and superstition" (Alkan, 2005, p. 11) without critically reflecting upon these two pivotal terms. In his article on Cevdet's conception of religion, Osman Demir proposes major subcategories related to Cevdet's understanding of religion, such as his association of religion and reason or his juxtaposition of religion with moral virtues and conscience. However, his conclusion that Cevdet pursued an "ideological reductionism which aims to melt religion into materialism" (Demir, 2011, p. 28) does not encapsulate this figure's complex writings on religion.

While materialist or functionalistic conceptions might lie at the heart of Cevdet's conception of religion his approach to religion was driven by various ideologies or currents of thought that he intermingled differently under different socio-historical circumstances. Accordingly, even though it exceeds the scope of this article to offer a comprehensive analysis of Cevdet's ideas and arguments on religion, his Baha'ism essay provides an important lens to identify some of the shifts in his thinking as well as the state mechanisms that determined the limits and manners of what could be publicly said about religion in general and Islam in specific. 


\section{Abdullah Cevdet and His Journal İctihad}

Similar to numerous other Ottoman intellectuals, Abdullah Cevdet [Karlıdağ]' (1869-1932) had several interests. A medical doctor by training, he was also a translator, poet, and public intellectual (Alkan, 2005, p. 2). During his medical training he was exposed to the prevalent intellectual trends of his time, primarily biological materialism (Hanioğlu, 2005, pp. 41-44). The medical school also influenced his political affiliations: Cevdet and his schoolmates established what would become an important political society that paved the way for the Committee of Union and Progress (CUP), a pivotal political party and the main actor in Ottoman politics from the last decade of the nineteenth century until the empire's 1922 dissolution. From that point on, Cevdet's intellectual and political affiliations cost him many years in exile; however, it also led to his career in journalism.

While living in Europe he began publishing İctihad, his most prominent periodical that remained in circulation from 1904 until his death in 1932. As it became the medium of expressing his political dissatisfaction with the Ottoman regime, particularly with Sultan Abdulhamid II (r. 1876-1909), he was forced to leave Europe as well; he eventually settled in Egypt and published İctihad there. After the sultan's deposition and the CUP's formation of a government, Cevdet returned to Istanbul, broadened the writers' cadres of Ictihad, and issued it from there. Owing to his ideas on religion and Islam, Ictihad was repeatedly a target of censorship and subjected to temporary closures. Furthermore, fractures arose among its writers. ${ }^{2}$

After 1910, Cevdet faced political and intellectual opposition, for the chasm between him and others-intellectuals and politicians alike-began to widen. He was appointed to the Directorate of Public Health in 1919 but did not hold the position for very long for numerous reasons, among them his writings on religion in ictihad. The political circumstances associated with the sultan's deposition, the CUP's rule, and then the establishment of the Republic did not significantly change the level of opposition directed against his journal and himself. Despite being one of the key figures who paved the way for the CUP's creation, his subsequent positions moved him progressively further away from those political circles.

Although Cevdet remained a public figure during the empire's last years and the Republic's early years, his intellectual and political views continued to cause him trouble. Some of his ideas, particularly those on religion, science, and civilizational achievements, might have influenced the thoughts and policies of the Republic's founders, primarily Mustafa Kemal [Ataturk], and yet he was denied any major political role. ${ }^{3}$ Although in 1925 Mustafa Kemal is said to have told Cevdet that "now," it was time for them "to bring them [his writings/ ideas] to realization" (Hanioğlu, 2011, p. 23), he did not choose Cevdet as a deputy to the Turkish Grand National Assembly. This is particularly striking when one finds out that two other İctihad writers, Kılıçzade İsmail Hakkı and Celal Nuri, were selected as parliamentary

1 This is the last name he adopted after 1934 Turkish surname law. Throughout this article the surnames individuals adopted are introduced in brackets; but their first names are used.

2 For instance, the conflict between Celal Nuri and Abdullah Cevdet, as touched upon later in this paper.

3 This requires a thorough examination on its own. For an important source that sheds light on the Young Turks' intellectual contribution to the formation of Mustafa Kemal's ideas on religion, see Hanioğlu (2011), particularly chapter three, "The Scientism of the Young Turks." 
deputies. Cevdet's political stances during and after World War I, such as his defense of the British mandate for Turkey or enrollment in the Kurdish separatist movement resulted in his political isolation (Hanioğlu, 1981, pp. 320-321). In that regard, it is also likely that while the Republican elites were influenced by and implemented his thought, as M. Kemal had phrased it, they chose to leave him behind the scene in order to avoid the controversies surrounding him. For example, he was still being sued in 1925 for his writings on Islam and Prophet Muhammad in his Baha'ism article. Nonetheless, throughout these years íctihad continued to be published and serve as the main outlet for Cevdet's views.

\section{Controversies around Cevdet's Translations}

Cevdet's publications on religion and Islam generated some of the most heated controversies and polemics among the intellectuals, the ulama, and the reading public. He translated several books into Turkish, including major works on materialism. ${ }^{4}$ Yet in the post-1908 Ottoman intellectual environment, his translation of Dutch Orientalist Reinhart Dozy's (1820-1883) Het Islamisme ignited one of the most vigorous debates. Cevdet translated it from its French edition, Essai sur l'histoire de I'Islamisme (Essay on the History of Islam) and into Ottoman Turkish as Tarih-i Islamiyet (History of Islam). He published it in 1908 in Egypt, most likely to circumvent Istanbul's approval and censorship mechanism, which were not so strictly enforced there. By the time Istanbul censored it in 1910, it had already received important public attention because it was "the first time a book openly critical of Islam and its prophet had been published in Turkish and received wide distribution" (Hanioğlu, 1997, p. 137).

Major Islamic periodicals of the time had been approached by readers demanding that the ulama and other intellectuals respond to Cevdet's preface and refute Dozy's assertions about the Prophet Muhammad. ${ }^{5}$ Although they criticized Cevdet for translating a work that targeted Islam and its Prophet (making various claims about Muhammad's hysteria and epilepsy as elements of revelation), more disconcerting for them was Cevdet's introductory preface that, instead of being a simple introduction, answered the question of who is a Muslim. In fact, he compared the non-Muslim Dozy with practicing Muslims and actually claimed Muslimness for him.

According to Cevdet, Dozy had conducted painstaking and objective research on the history of Islam (Cevdet, 1908). Even though his book criticized and offered contradictory ideas about the Prophet, Cevdet opined that the Dutch scholar embodied true Islam more than many practicing Muslims did and grounded this argument on criteria set by the Prophet himself. Cevdet reasoned that if, as the Prophet put it, "religion is composed of muamalat," which he defined as "social interaction or relations," then Dozy, the scholar who had "devoted his entire life to teaching and study" and who "endeavored to enlighten the minds of God's people and to benefit them, the human mind, and to benefit people, is a thousand times more Muslim" (Cevdet, 1908, "ifade," para. 2). Likewise, he asserted that if, as the Prophet had also said, "the Muslim is one from whose hand and tongue people are 
safe," then Dozy, through his meticulous research, embodied that safety for other people. In the same way, he held that this particular scholar exemplified the prophetic statements that "The best of men is the one who is most useful to people" and "One hour's search for knowledge is better than a thousand year acts of worship"-maxims that he saw abundantly evidenced in Dozy's scholarship (Cevdet, 1908, "ifade," para. 2).

It is not hard to grasp the opposition of the readers, intellectuals, and scholars to this method of reasoning, for it turned the criteria set by religion, or its prophet, upside down in order to affirm his views as to what counts as true religion. At the heart of Cevdet's preface lay both an advocacy of the objective, scrupulous examination of Islam's history and a conception of Islam and Muslimness as embodied in acts of benevolence toward society and humanity. It seems that Cevdet developed these ideas further over the following years, especially within the historical unfolding and aftermath of World War I. His encomium of Baha'ism was penned in 1922 within the context of World War I and the great devastation it wrought, both of which strengthened his search for a truly humane religion and allowed him to denounce the relationship between established religion and conflict and violence. He was no longer promoting true Islam in the form of meticulous scholarly works, but advocating true religion as one driven by compassion, benevolence, and peace. In the same way, as will be detailed below, he was not simply condemning the inaccurate, partial histories of Islam written by Muslim scholars, as opposed to that of Dozy, but rather the very historical trajectory of Islam itself as it unfolded even during the time of the Prophet, which, unlike the late nineteenth-century religious movement of Baha'ism, had moved far away from the ideals of fraternity, harmony, and peace.

\section{Baha'ism in the Ottoman Press}

A series of articles about Baha'ism had appeared in İctihad during 1922, right before Cevdet published his essay. Indeed, as Cevdet emphasized during his court defense, other Ottoman periodicals devoted sections to this particular religion in their pages; Ictihad had just followed in their footsteps (Cevdet, 1922b, p. 3097). ${ }^{6}$ However, Cevdet's essay so outraged the broader public and government agents that he was sued and sentenced to two years of prison in April 1922.7 He never served this sentence, however, because in 1926, while he was still appealing it the law against disparaging prophets (enbiyaya ta'n fezahat-i lisaniyye) was removed from the penal code (Alkan, 2005, p.11). What factors can explain this determined legal prosecution? The answer lies in his essay's content and Ottoman censorship policies as regards religious publications, both of which will be examined at length below. However, before that, a brief comparison with the other essays on Baha'ism that appeared in Ictihad but had no negative repercussions will prove that there was something more to this ongoing opposition.

Emin Ali's three articles on Baha'ism in Ictihad disclose that the Ottoman publication authorities considered a scientific or scholarly investigation of Baha'ism to be legitimate.

6 Cevdet gives the names of the periodicals as well as dates and titles of these other articles on Baha'ism in Ottoman periodicals. 
Indeed, even praising it was, to a certain extent, approved. However, Cevdet's article caused a large outcry precisely because of how he praised it as an alternative to Islam (and even Christianity) and attacked other religions and their prophets. Ali praises Baha'ism as a religious movement of affection and friendship among humanity (Ali, 1922a, p. 2985) and as a religion of peace (Ali, 1922b, p. 3001); however, unlike Cevdet, he never draws explicit comparisons between it and other religions, especially by underscoring the latters' divergence from Baha'ism's humanitarian ideals. Thus the articles in question are informative entries on the historical background and development of the faith and its founders, as well as its basic principles and moral teachings. As their titles emphasize, these essays are "scholarly examinations of the Baha'i movement." Whenever Ali shows his attraction to this religious movement, he stresses that it is neither a new religion nor one that rejects established religions; to the contrary, it encompasses the "true teachings of all other religions and philosophies" (Ali, 1922a, p. 2985). In this regard, unlike these other writings on Baha'ism, Ottoman state authorities, particularly the Tetkik-i Mesahif ve Müellefat-ı Şeriyye Meclisi and the Daru'l-Hikmeti'l İslamiye, considered Cevdet's essay an attack on the Prophet Muhammad, an insult to Muslim sentiments, and an encomium of Baha'ism (as opposed to Christianity and Islam) as the true religion of love and mercy.

\section{Baha'ism in Cevdet's Essay: A Religion of Nations, Peace, and Humanity}

Cevdet's article, entitled Mezheb-i Bahaullah, Din-i Ümem (The Sect of Baha'ism, Religion of Nations), ${ }^{8}$ is his idealization of the Baha'i movement as a genuinely humanitarian religion. While he did not use the term humanitarian his description of it as the "religion of love and mercy" and as a "movement of light and peace" (Cevdet, 1922a, p. 3015) seems to have embodied the late nineteenth- and early twentieth-centuries' emergent notion of humanitarianism and its influence upon the conception of religion. ${ }^{9}$ Cevdet defined Baha'ism as a religion of love, mercy, and peacefulness, characteristics that for him should be inherent in any religion (Cevdet, 1922a, pp. 3015-3017). On one hand, he illustrated how Baha'ism embodies the principles of affection, compassion, and caring for other beings and institutes peace and nonaggression. On the other hand, he criticized Christianity and Islam for falling short of these ideals.

Cevdet's praise of Baha'ism as a humanitarian religion, one of mercy and love superior to Islam and Christianity (at least in their historical manifestations), needs to be considered within the parameters of his idealization of post-World War I calls for peace and nonviolence. Hanioğlu notes that Cevdet's interest in and search for pacifism and world peace

8 It is possible to translate din-i ümem as "religion of nations" as well as "a world religion." Necati Alkan translated it as "a world religion." See Alkan (2005, p. 1).

9 Cevdet's thought in this respect deserves a thorough comparative investigation of the emergence and application of humanitarianism in the Ottoman Islamic context vis-à-vis its development in Europe, which made original reference to Jesus' human nature and the Christian idea of redemption. For a brief discussion, see Asad (2014). While the development of humanitarianism in European thought and practice might be traced originally to its mid-nineteenth-century theological renderings of Jesus' human (as opposed to the divine) nature, the Christian idea of redemption, along with the notion posited by intellectuals such as Pierre Leroux of the "religion of humanity" (per Asad), Cevdet viewed humanitarianism as promoting human benevolence, mercy, and peace, all of which directly shape the definition of religion. 
were reflected in his ideas on the Baha'i religion (Hanioğlu, 1981, p. 338). ${ }^{10}$ However, I think that this argument deserves further emphasis and investigation, for these ideas about peace and solidarity as ideals were on his mind even before the World War I years. ${ }^{11}$ Cevdet and fellow Ictihad author Celal Nuri [ileri] had a major dispute precisely for this reason. ${ }^{12}$ Nuri offered a very harsh critique of Europe and Europeans in the aftermath of the Balkan wars, declaring that they could no longer be loved and shown affection for they had become enemies and had to be regarded with enmity (Nuri, 1914). Cevdet, however, refuted this suggestion and refused to derive such a conclusion from the Balkan wars, which most other Ottomans experienced as a great catastrophe (Cevdet, 1914, p. 1980). Even within this context of power dynamics he idealized friendship, solidarity, and peace among nations, more specifically Europeans and Ottomans. Over the years, his position only became more entrenched.

Although his essay explicitly criticized the Prophet and both Islam and Christianity as religions of violence, confrontation, and battles, his subsequent writings underscored the historical context in which he had written the piece: the destruction caused by World War I and his own search for a truly peaceful religion (Cevdet, 1922b, pp. 3096-3097). In this regard, unlike Ali who emphasizes that Baha'u'llah promoted peace and tolerance and formulated the establishment of a league of nations and an international court of justice to solve conflict among nations even before World War I broke out (Ali, 1922b, p. 3001), Cevdet stressed his appeal to Baha'ism specifically within the framework of this very destructive war. While he might have undertaken it as a defense strategy in court, it is still important to examine his appeal to Baha'ism within this historical moment, one characterized by calls for humanitarianism and the search for a humane and compassionate religion. Thus scholars need to conduct further research on the following questions: Did other religious movements at this time advocate peace and friendship? If so, why was Baha'ism so appealing to Cevdet and other Ottoman intellectuals at this time? Did his perspective on Baha'ism remain same in late 1920 s and early 1930 s? If not, how did it change?

\section{Islam in Cevdet's Article}

While Cevdet idealized compassion and peace in Baha'ism, in the same essay he compared its teachings with those of Islam and Christianity. He stressed that the latter two's failure latter lay in their contradictory doctrines as well as historical trajectories, which had diverged from the virtues of a humanitarian religion. Cevdet began his essay with a rhetorical question, asking whether Baha'ism is exceptional as a religion of compassion and love, given that one could rightly posit that no religion advocates "animosity and enmity" (Cevdet, 1922a, p. 3015). He then cited examples from the Bible and the Qur'an and Hadith endors-

10 For Cevdet's 1922 engagement with a society of pacifists, see Alkan (2005, p. 10).

11 Similarly, even though Alkan notes that Cevdet was attracted to Baha'ism as a "new religious movement which, in his eyes, could have led society to the world peace humankind has sought for generations" (Alkan, 2005, p. 11), he does not fully unpack how much World War I impacted the formation of Cevdet's ideas about Baha'ism.

12 For an important essay that examines Cevdet's ideas on Europe and offers a detailed comparison of his debate with Nuri, see Buzpınar (2005). 
ing compassion, affection, and mercy, thereby implicitly proposing that other religions also embrace Baha'ism's ideals. ${ }^{13}$ But then he acknowledged that some verses and hadiths contradict these ideals, even though he also seemed to be defending Islam by offering alternative interpretations of such texts, ${ }^{14}$ a method that Cevdet had employed in his previous writings, as demonstrated in his preface to Tarih-i Islamiyet. Likewise, although he opened his essay with the proposal that Christianity and Islam, as revealed in the Hadith and the scriptures, do not endorse killing, hatred, or enmity but rather encourage fraternity, mercy, and affection among humans, he went on to draw a distinction between their original message and how they had developed over time.

He implied that the historical development and unfolding of Christianity and Islam had caused them to move away from their original ideals of peace, nonviolence, and mercy. In his words, "neither the history of Christianity nor that of Islam stayed true to these principles of mercy" (Cevdet, 1922a, p. 3015). Even his word choice for these particular religions is telling in this regard: He used Iseviyet and Muhammadiye for Christianity and Islam, respectively, instead of such common Ottoman Turkish terms as Nasraniyet for Christianity and din-i mübin-i İlam or İslamiyet for Islam. This decision reflects his distinction between the true religion revealed by God and how each religion had developed around its prophet. Although a number of his contemporaries made the same distinction between the original intention of revelation and its historical development as part of their efforts to reform Islam, ${ }^{15}$ what is outstanding in Cevdet's case is that in contrast to most of these intellectual endeavors, he problematized the practices and development of Islam even during the time of the Prophet Muhammad.

In other words, he maintained that not even the earliest form of Islam always encapsulate the ideal, true form of Islam. In his court defense, after denying that his article insulted Islam's Prophet, Cevdet explicitly voiced the idea that prophets, including Muhammad, are not exempt from minor slips, mistakes, or errors (zelle) (Cevdet, 1922b, 3101). The concept of zelle has been formulated since early Islam as part of 'isma (impeccability), the idea that the prophets are immune from sin. Muslim scholars and theologians have debated this notion at great length in terms of whether the prophets were completely free of error and mistakes, whether this applied only to their post-prophetic mission, and in what ways they could have committed errors (Madelung, 2014). While Cevdet's reference to zelle is, in this respect, an appropriation of an already familiar concept in the Islamic tradition, the way he used it to shape his legal defense is significantly novel: citing historical incidents to address the errors prophets committed during their prophethood. For example, he considered the

13 Cevdet cited Jesus' saying "Love one another" and Muhammad's being sent as rahmeten lilalemin (a mercy for all worlds), and referred to hadith in which Muhammad encourages people not to hate or envy one another but to be brothers. He also quoted the hadith he had used to defend Dozy, which defines a Muslim as one from whose hand and tongue others are safe.

14 For instance, regarding the verse qatlu fi sebilillah (kill in the path of Allah), after accepting its unquestionable status through another Qur'anic verse that states God cannot be questioned about what he does (Ia yusalu 'amma yef'alu), Cevdet asserted that qatlu here does not mean "to kill" but, rather, "to strive for," as explained in the Qur'anic statement cahedu fi sebilillah (strive in the path of Allah).

15 For a similar and comparative case, not to mention a very intriguing discussion on this issue of religion, truth, and historical context, see Shissler's analysis of contemporary intellectual Ahmet Ağaoğlu's elaborations on the "woman question." See Shissler (2002, pp. 137-151). 
prophet Muhammad's battle with and subsequent treatment of Kurayza, ${ }^{16}$ one of Medina's Jewish tribes, a violation of the principles of love and mercy (Cevdet, 1922a, p. 3015). His Baha'ism article details this tribe's treatment, narrating how the men were beheaded, their women and children sold as concubines and slaves, and a beautiful young woman was saved for Muhammad (Cevdet, 1922a, p. 3015). ${ }^{17}$ The same holds true for his assessment of the Crusades and of various prophets' expeditions against those whom they considered infidels (Cevdet, 1922a, p. 3015).

Cevdet highlighted that historical religion, meaning what happens to a religion over time, proved hard for ordinary believers to understand. During his court defense, he referred to his coverage of almost incomprehensible historical events during and after Muhammad's lifetime, such as the Battle of Karbala (680), during which Muslims killed others, one another, and even the Prophet's grandchildren (Cevdet, 1922b, pp. 3099-3100). Although he contended that Muslim scholars were obliged to explain such events, by emphasizing the difficulty of making sense of a revealed religion's historical trajectory, in this case Islam, he seems to have implied that he rejected the historical religion in favor of the true, essential religion, even though its own prophet might have altered it. Thus he distinguished between prophets' true prophetic missions and their historical individual and human lives, which were vulnerable to error and mistakes. As he put it, "the prophets, in conveying the lordly revelation, are absolutely immune from mistake and error." Yet in other matters, as also mentioned in the Qur'an, they are beşer (human beings) (Cevdet, 1922b, p. 3100).

Accordingly, in his essay Cevdet criticized, condemned, and questioned the historical trajectories of Christianity and Islam for having strayed far from their ideal doctrinal principles of love and mercy and targeted the individual, personal shortcomings of Jesus and Muhammad. In Baha'ism and its founders, namely, Baha'u'llah (1817-1892) and his son Abdu'l Baha (1844-1921), he found a contrary example. He proposed that Baha'ism, both in its doctrinal principles and in the persons of its founders, upheld the commitment to be a religion of mercy, compassion, love, peace, and light. He illustrated this claim by quoting Abdu'l Baha's sayings (Cevdet, 1922a, pp. 3016-3017) and citing nonviolent and merciful practices and acts. According to Cevdet, unlike Jesus or Muhammad, the founders of Baha'ism did not claim to be prophets. Nor did they hurt anyone. On the contrary, they would have preferred to be killed rather than kill a single person (Cevdet, 1922a, p. 3016).

Tacitly referring to the Qur'anic and Islamic image of Muhammad as "a mercy to all worlds,"18 he claimed that this was indeed true of Baha'ism's founders. Thus, while at least implicitly condemning the former prophets, primarily Muhammad, for killing other human beings, Cevdet esteemed Baha'ism's originators for being truly compassionate and peaceful, eager to "enlighten" and "warm" the entire universe through light and peace instead of through blood, weapons, and war (Cevdet, 1922a, p. 3017). In that regard, he further asserted that

16 For this tribe and the event Cevdet referred to, see Watt (2014).

17 Cevdet reported this historical event by citing Abu'l Fida's (1273-1331) book on pre-Islamic and Islamic history: Kitab-ı Muhtasar fi ahbar el-beşer. See Gibb, 2014. Since the book had been printed in Istanbul during 1870 , it likely received the necessary approval, making it even more likely that Cevdet's presentation of this incident, more than his book's coverage of it as such, was at stake for the reviewing councils that condemned his Baha'ism essay.

18 See, for instance, Qur'an 21:107. 
Baha'ism did not negate Islam, at least concerning the latter's ideal form rather than its historical trajectory. For him, one could be a Baha'i and a Muslim at the same time because Baha'ism, as the religion of mercy and love, does not demand that people give up their birth religions (Cevdet, 1922a, p. 3015).

\section{Religious Censorship of the Press}

Several Muslim intellectuals and scholars refuted this article in contemporary periodicals. ${ }^{19}$ However, as this paper focuses only on the two Meşihat councils' reactions, couple of points needs to be noted before examining these responses at length. First, the newspaper Tevhid-i Efkar, in which some of these refutations appeared, had been on the receiving end of the Tetkik-i Mesahif ve Müellefat-ו Şeriyye Meclisi's criticism and censorship on a different topic. ${ }^{20}$ Alkan's observation that Tevhid-i Efkar was "one of the leading conservative newspapers that attacked the Baha'i religion and Cevdet" (Alkan, 2015, p. 6) is misleading, for while it might have articulated ideas close to those of the Tetkik-i Mesahif ve Müellefat-ı Şeriyye Meclisi or serve as a "conservative" forum, as in the case of Cevdet's Baha'ism essay, in other cases it printed articles that expressed rather radical views. Indeed, it might even be (and indeed was) censored by the Ottoman authorities.

Second, Cevdet's Baha'ism article was just one of the publications condemned and censored by the Ottoman Islamic print approval council, Tetkik-i Mesahif ve Müellefat-ı Şeriyye Meclisi. This council's jurisdiction encompassed overseeing, approving, or rejecting and censoring all Islamic books and periodicals. Its control over the religious content of newspapers and journals was strengthened especially during the post-1910 era. In this regard, besides Cevdet's essay the council targeted other essays, too, in contemporary periodicals (Polat, 2015, pp. 85-134).

Third, in the case of both this particular council as well as the other Meşihat council established after World War I, Daru'l-Hikmeti'l İslamiye, this incident of the post-publication censorship illustrates the significant presence of the Ottoman religious censorship apparatus on publications even in the aftermath of World War I. Although numerous studies emphasize the strong political censorship of the Allied forces, the Ottoman government, or the emerging new regime in Ankara, the empire's religious censorship during these years are mostly neglected. Yet, the last years of the Ottoman Empire and the transition to the Republic continued to be marked by these censorship mechanisms that were applied to religious content in publications. Cevdet's Baha'ism essay is only one outstanding example of this governance (Polat, 2015, pp. 137-192).

In contrast to the overemphasized censorship implemented for political ends during the Armistice period, the controversy around Cevdet's article and the mandate assigned to the Meşihat councils' oversight demonstrate that censorship was also motivated by con-

19 For instance, Mustafa Sabri and Tahir'ül Mevlevi responded to Cevdet in Peyam-ı Sabah in March 1922. For a translation of one of these refutation articles, see Alkan, (2015, pp. 15-17).

20 See the debate on Mary's virgin conception of Jesus and the censorship of these essays in Tevhid-i Efkar (Polat, 2015, pp. 148-170). 
cerns beyond directly political causes. This is not to suggest that his article had no political consequences. On the contrary, as the Meşihat councils pointed out, his open criticism of the Prophet Muhammad and Islam caused the Ottoman imperial authorities extra trouble, especially at a time when the imperial center needed the help of other Muslims. His publication of these essays in the imperial capital, no less, led the Meşihat councils to assert that they were one of the factors fueling, for instance, the Meccan governor's rebellion against the Ottoman sultan and caliph. Even so, the jurisdiction of the Tetkik-i Müellefat-ı Şeriyye and Daru'l-Hikmeti'l İslamiye did not primarily cover the political arena in the sense of vying for sovereignty against the Allies or suppressing the Anatolian nationalist movement. Rather, both Meşihat councils targeted Cevdet's ideas within the accepted legal framework of safeguarding the public's Islamic convictions and religious sensibilities.

\section{The Meşihat Councils' Legal Framing of Cevdet's Essay}

The Tetkik-i Mesahif ve Müellefat-ı Şeriyye Meclisi stressed the legal obligations of publishers and authors to submit articles with religious content to its oversight. It demanded that legal proceedings be brought against Cevdet because he had ignored this legal principle (Tetkik-i Müellefat-ı Şeriyye Defterleri 5/5, 1922, p. 202). Regarding the article's content, the council primarily challenged its claims about the Prophet and the fate of the Jewish Kurayza tribe. Furthermore, when Cevdet sent his response to the criticisms of his original to another newspaper, Peyam-ı Sabah, the council targeted it as well due to the author's non-compliance with the regulation not to print Qur'anic verses and hadiths in daily newspapers (Tetkik-i Müellefat-ı Şeriyye Defterleri 5/5, 1922, p. 202). Cevdet, however, rejected the latter criticism on the grounds that he had sought the council's approval before printing his response (Cevdet, 1922b, 3101; Cevdet (1922c, 2).

In its records, this particular council always composed short entries about the articles it criticized. Its response to Cevdet's Baha'ism essay followed this norm, even though this entry was slightly more extensive than the council's other incidences of censorship. Yet, in all cases its main tool was the legal framework that obliged publishers to submit every publication to its approval and prohibited their publishing of any hadiths or Qur'anic verses in full Arabic script in daily newspapers.

The other Meşihat council, the Daru'l-Hikmeti'l İslamiye, elaborated more on Cevdet and his essay. Indeed, its condemnation of Cevdet predates his Baha'ism essay, for it had targeted Ictihad in 1919, three years before the publication of this essay. It offered similar criticisms in both cases. As regards İctihad, Daru'l-Hikmeti'l Islamiye had accused it of containing articles and essays "that are not grounded in any scholarly [or] moral foundation and are written exclusively to pursue the objective of disparaging the religion of Islam or its obligatory pillars" (ilmi, ahlaki hiçbir mevzua müstenid olmayan ve münhasıran din-i İlamı veya erkan-ı zaruriyesini tezyif gayesini gözetilerek yazılmış) (Daru'l-Hikmeti'l İslamiye Defter 1786, 1919, n.p.). The council continued to assert that "it is incomprehensible to understand which nation and religion [the authors of these articles] belong to and follow," yet their publications directly "insult Islam, which is the official religion of the state" (devletin din-i resmisi olan İslam'a hakaret) (Daru'I-Hikmeti'l İslamiye Defter 1786, 1919, n.p.). Accordingly, similar 
to the Tetkik-i Mesahif ve Müellefat-ı Şeriyye Meclisi, it demanded that the Meşihat enforce the relevant penal decrees against ictihad's writers. ${ }^{21}$

Similar concerns were expressed in the second case. Daru'l-Hikmeti'l İslamiye declared that Ictihad produced negative repercussions in the Ottoman imperial capital because it targeted the state religion, Islam. It further claimed that the journal's articles negatively influenced the faith of individual believers as they heightened the political risks for the empire itself. The council stated that Cevdet's essay "was written in an aggressive way that influenced Muslim hearts by making them quiver" (kulub-u Müslimini ra'şedar-ı teessür edecek derecede mütecavizane yazılmış) (Daru'I-Hikmeti'l İslamiye Defter 1786, 1922, n.p.). As for the political consequences of such publications, it referred to another of Cevdet's articles, written during World War I, that criticized Qur'an 4:11 ("the male shall have the equal of two females' share"), on the grounds that it provided an excuse for the governor of Mecca to rebel against the Ottoman Empire and the caliph (Daru'l-Hikmeti'l İlamiye Defter 1786, 1922, n.p.) Since the journal already had a "bad reputation" (şöhret-i seyyie) among Muslims, the council proposed, similar to its 1919 petition, that ictihad face legal action and punishment (Daru'l-Hikmeti'l İslamiye Defter 1786, 1922, n.p.).

Daru'l-Hikmeti'l İslamiye also penned a refutation-like essay in response to the ideas articulated by Cevdet in his Baha'ism article. At the center of this rebuff was the council's own interpretation of the historical events narrated by Cevdet, bolstered by claims that he had failed to provide the complete historical background of this particular battle because his primary aim was "to call people into a new religion" (Daru'l-Hikmeti'l İslamiye Defter 1787, 1922 , n. p.). It further maintained that while it was important for scholars and intellectuals to refute Baha'ism and other harmful sects, Ictihad, as a den of mischief (fesat ocağı), needed to be shut down immediately and its owner had to punished (Daru'l-Hikmeti'l İslamiye Defter 1787,1922, n. p.). In that regard, both Meşihat councils appealed to and deployed legal means in their critique of Cevdet and ictihad. As part of the nineteenth century reforms, Islam was made the state religion in the Ottoman Empire and this approach and legal framing was tantamount to protecting public Islam, overseeing which ideas about Islam were promoted to people and safeguarding against injury on their religious sentiments.

\section{Conclusion}

The Ottoman imperial administration established important control and regulation regimes on all printed texts. Books and periodicals, regardless of genre and format, were subjected to the Ottoman administrators' approval. Ottoman religious-political establishment paid great attention to Islamic publications or articles, essays, and other forms of printed material that contained ideas and arguments about Islam. Approval or rejection was inevitable. Even if the work-in-question circumvented inspection before publication, it could still subsequently be prohibited and censored, and legal action could be taken against its publishers, primarily the author.

21 The council also stated that because these authors did not seem to respect any "religions in force" (edyan-I meriyye) in the Ottoman Empire, it was important to correct their religious affiliations on their ID's to clarify issues related to civil law, primarily marriage. Although not explicitly mentioned, I think that the issue of marriage and religious affiliation was raised here to address the Islamic rules on interreligious marriages and marriages to partners of no religion. 
Cevdet's Baha'ism article, although only one example in this regard, is nevertheless an outstanding case on several fronts. While Cevdet's publications prompted controversy and debate in Ottoman intellectual realm for decades, this particular essay constituted a cutting edge for his personal articulations on religion, encapsulating the evolution of his assessment of religions, particularly Islam, within the specific context of World War I and its aftermath. The essay illustrates the significant ways in which the historical context (re) shaped the ideas of a reformist intellectual. While Cevdet sought in Baha'ism the ideals of a religion of peace and nonviolence after the war's catastrophic outcomes, the censorship organs that criticized his article's claims deployed contemporarily accepted categories and rationales to launch legal proceedings against him.

For the Meşihat authorities, Cevdet's assessment of Islamic history and the Prophet's life was inaccurate and detrimental to the public's upheld beliefs and sentiments about Islam. The state authorities were granted the authority to inspect, oversee, and if necessary fight against (in the form of pursuing a law case) those writings they considered inappropriate. What was judged inappropriate entailed manifold criteria. In this particular case, these were primarily insulting the official state religion, offending public's Islamic beliefs and sentiments, and calling them into a new religion. Not only was his advocacy of Baha'ism as an alternative to Islam (and Christianity) as a movement of peace at stake, but so was his confrontation with the historical religion of Islam and his assessment of its historical development or unfolding even at the time of the Prophet.

In terms of Cevdet's ongoing quest, the present moment made it hard for him to grasp the past. Instead, he felt an urgent need to listen to contemporary calls for a humane and humanitarian religion. But in the eyes of others, primarily those Ottoman scholars and intellectuals serving in the Meşihat councils, Cevdet's interpretations of the Islamic past were neither comprehensive nor accurate. Moreover, the state would not grant him the authority to disseminate his views to the general public without receiving the approval of the Meşihat councils and state administrators.

\section{References}

Ali, Emin. (1922a). Bahai hareketi hakkında ilmi bir tetebbu-II. İctihad, (142), 2983-2985.

Ali, Emin. (1922b). Bahai hareketi hakkında ilmi bir tetebbu-III. Ictihad, (143), 2999-3003.

Alkan, N. (2005). "The Eternal Enemy of Islām”: Abdullah Cevdet and the Baha'i Religion. Bulletin of the School of Oriental and African Studies, $(68,1), 1-20$.

Ayluçtarhan, S. (2007). Dr. Abdullah Cevdet's Translations, 1908-1910: The Making of a Westernist and Materialist 'Culture Repertoire' in a 'Resistant' Ottoman Context. Ph.D. thesis. Boğaziçi University, Istanbul.

Buzpınar, Ş. T. (2005). Öteki' üzerinden hesaplaşma: Celal Nuri ve Abdullah Cevdet'in Avrupatartışmaları hakkında bir değerlendirme. Divan Illmi Araştırmalar, (19), 151-176.

Cevdet, A. (1908). Ifade-i mütercim. In R. Dozy, Tarih-i Islamiyet (A. Cevdet, Trans.). Mısır: Matbaa-yı İctihad.

Cevdet, A. (1914). Şime-i muhabbet. İctihad, (89), 1979-1984.

Cevdet, A. (1922a). Mezheb-i Baha'ullah, din-i ümem. íctihad, (144), 3015-3017.

Cevdet, A. (1922b). Muhterem Hakimler! İctihad, (149), 3095-3101.

Cevdet, A. (1922c, 13 Receb 1340/1922). Fazıl-ı muhterem Mustafa Sabri Efendi hazretlerine. Peyam-ı Sabah, 2.

Daru'l-Hikmeti'l İslamiye Defter 1786. (1922). Meşihat Arşivi. 
Daru'l-Hikmeti'l İslamiye Defter 1787. (1922). Meşihat Arşivi.

Demir, O. (2011). Doktor Abdullah Cevdet'te din algısı. Insan ve Toplum, 1 (2), 5-28.

Gibb, H.A. R. (2014). Abu'l-Fida. Encyclopaedia of Islam. Retrieved from referenceworks.brillonline.com.

Hanioğlu, Ş. (1981). Bir siyasi düşünür olarak Abdullah Cevdet ve dönemi. İstanbul: Üçdal Neşriyat.

Hanioğlu, Ş. (1995). The Young Turks in Opposition. New York: Oxford University Press.

Hanioğlu, Ş. (1997). Garbcılar: Their Attitudes toward Religion and Their Impact on the Official Ideology of the Turkish Republic. Studia Islamica, (86), 133-158.

Hanioğlu, Ş. (2005). Blueprints for a Future Society: Late Ottoman Materialists on Science, Religion, and Art. In Elizabeth Ozdalga (Ed.), Late Ottoman Society: The Intellectual Legacy. London: Routledge Curzon.

Hanioğlu, Ş. (2011). Ataturk: An Intellectual Biography. Princeton: Princeton University Press.

Hatiboğlu, İ. (1999). Osmanlı aydınlarınca Dozy'nin Tarih-i Islamiyyet' ine yöneltilen tenkitler. İslami Araştırmalar Dergisi, (3), 197-212.

Madelung, W. (2014). Isma. Encyclopaedia of Islam. Retrieved from referenceworks.brillonline.com.

Nuri, Celal. (1914). Şime-i husumet. İctihad, (88), 1949-1951.

Polat, A. (2015). Subject to Approval: Sanction and Censure in Ottoman Istanbul (1889-1923). Ph.D. thesis. University of Chicago, Chicago.

Shissler, H. (2002). Between Two Empires: Ahmet Ağaoğlu and the New Turkey. London: I.B. Tauris.

Tetkik-i Mesahif ve Müellefat-ı Şeriyye Meclisi Defterleri 5/5 (Genel No: 5293). (1922). Meşihat Arşivi.

Watt, M. (2014). Kurayza. Encyclopaedia of Islam. Retrieved from referenceworks.brillonline.com. 